九州大学学術情報リポジトリ

Kyushu University Institutional Repository

\title{
FAUNA OF SPIDERS IN A PADDY FIELD IN SUWEON, KOREAI'
}

Okuma, Chiyoko

Lee, Moon Hong

Hokyo, Nobuhiko

https://doi.org/10.5109/2375

出版情報 : ESAKIA. 11，pp.81-88，1978-03-31. Entomological Laboratory，Faculty of Agriculture， Kyushu University

バージョン :

権利関係 : 


\title{
FAUNA OF SPIDERS IN A PADDY FIELD IN SUWEON, KOREA ${ }^{1)}$
}

\author{
CHIуоко OKuMA \\ Entomological Laboratory, Faculty of Agriculture \\ Kyushu University, Fukuoka 812, Japan \\ M OON HONG LEE \\ Institute of Agricultural Sciences, Office of Rural Development \\ Suweon, 170-Korea \\ and \\ N овиніко Нокуо 2 ) \\ Kyushu National Agricultural Experiment Station \\ Chikugo, Fukuoka 833, Japan
}

\section{Introduction}

Previously, Hokyo et al. (1976) reported some important aspects in the population dynamics of rice leafhoppers in Korea where spiders in paddy fields seem to play an important role in damping the population growth of rice leafhoppers especially in northern regions. In this paper, we describe the fauna of spiders collected mainly from a paddy field in Suweon in 1975 and mention some characteristics of the fauna and its seasonal diversity.

\section{Fields and sampling methods}

A paddy field of ca. 10 a at Kotomoe, Suweon, was the main field for the regular census of rice leafhoppers and spiders without insecticide application (for the details, see Hokyo et al., 1976). Visual counting of spiders on 50-500 rice hills chosen systematically was conducted at 3-day intervals from June 12 to Sept. 29 in the central block delimited in the field. The remaining area of the field was divided into 3 blocks where collection of spiders was made by sucking with an aspirator and by sweeping with a butterfly net. Collection by sucking was made from mid June to early September in one of the three blocks selected by rotation at the time of visual counting census. A cage of acrylic plate (upper and bottom opened),

1) Contribution from the Entomological Laboratory, Faculty of Agriculture, Kyushu University, Fukuoka (Ser. 3, No. 46).

2) Present address: Okinawa Agricultural Experiment Station, Naha 903, Japan. 
$50 \mathrm{~cm}$ on a side and $40 \mathrm{~cm}$ in height, was used for enclosure of 3-6 rice hills per replication of sucking so as to prevent spider escape. Ten replications (six hills were enclosed per replication) were taken at each census during mid June to early July when spider densities were relatively low, but the sample size was reduced thereafter with the increase in spider density and plant growth. Collecting by sweeping was conducted from late June to mid September in each of the three blocks in parallel with the regular census except rainy days. Fifty strokes were made in each block at a time of collecting. Collected spiders were kept separately for dates and collecting methods in glass tubes containing $75 \%$ alcohol for later taxonomic examination.

Beside the above surveys, spiders were collected from paddy fields in the following districts: Pyongtek in Gyeonggi (June 27, by sweeping) ; Seochon in Chungbug (July 1, by sweeping); Gochang in Jeon-bug (Aug. 4, by sucking and sweeping) ; Boseong in Jeon-nam (Aug. 5, by sucking); Jinju in Gyeong-nam (Aug. 6, by sucking and sweeping) and Kimhae in Gyeong-nam (Aug. 7, by sucking and sweeping).

\section{Results and discussion}

Whole spiders collected by sucking and/or by sweeping in each district were shown in Table 1. Although a considerable numbers of nymphal stages (2nd instar to sub-adult) was involved in the sampled specimens, identifications of their belonging families were possible in most of the cases (see also Table 2). All the nymphs of Erigonidae and Clubionidae were difficult for further classification. A part of nymphs of Tetragnathidae were also difficult to identify. As the result, 12 families consisting of at least 21 species were known to be distributed in paddy fields in Korea. In the total of 1,347 spiders, Lycosidae occupied ca. $40 \%$; Tetragnathidae, $20 \%$; Erigonidae and Argiopidae, 12 and $11 \%$ respectively; Clubionidae, $7 \%$ : Theridiidae, $4 \%$; Thomisidae and Salticidae, 3 and $2 \%$ respectively. Spiders of Linyphiidae, Agelenidae, Oxyopidae and Gnaphoshidae were really rare in number of specimens collected. These figures, however, cannot be regarded as actual reflection of relative abundances of common families because spiders collected by sweeping tended to concentrate to those belonging to Tetragnathidae and Argiopidae.

Table 2 compares the results obtained by sucking and sweeping in the Suweon paddy field. There spiders on 450 rice hills were totally collected by sucking, and those collected by sweeping were attributed to the total of 2,100 strokes. Thus, roughly speaking, it might be well that sweeping gave at least 4 times greater number of spiders collected by sucking if no differential efforts existed between the two collecting methods. Clearly, such was unlikely for spiders belonging to Theridiidae, Erigonidae and Lycosidae (mostly Pirata subpiraticus). Spiders of the first two families are snarers and snarers with a hunting habit respectively, and their activities are mainly observable in lower part of rice hills except the time of dispersion. Lycosid spiders are active hunters at lower part of rice hills and near the ground surface. The four species of Tetragnathidae other than Pachygnatha clercki are snarers which prefer to settle themselves in upper part of rice hills, whereas P. clercki is a hunter like Pirata subpiraticus (Hamamura, 
Table 1. List of spiders collected from paddy fields at several localities in Korea (1975).

\begin{tabular}{|c|c|c|c|c|c|c|c|c|}
\hline \multirow[b]{2}{*}{ Family and species } & \multicolumn{8}{|c|}{ Locality } \\
\hline & A & B & $\mathrm{C}$ & $\mathrm{D}$ & $\mathrm{E}$ & $\mathrm{F}$ & G & Total \\
\hline \multicolumn{9}{|l|}{ ThERIDIIDAE } \\
\hline Achaearanea sp. & 32 & & & 1 & & & & 34 \\
\hline Enoplognatha japonica & 16 & & & & & 1 & 1 & 18 \\
\hline Theridion octomaculatum & & & & 1 & 1 & 2 & & 4 \\
\hline Theridion subpallens & 2 & & & & & & & 2 \\
\hline \multicolumn{9}{|l|}{ ERIQONIDAE } \\
\hline 0 edo thorax insecticeps & 13 & & & 9 & 1 & 2 & 11 & 36 \\
\hline Gnathonarium dentatum & 20 & & 1 & 3 & 4 & 3 & 1 & 32 \\
\hline Erigone prominens & 5 & & & 1 & & & 1 & \\
\hline $\begin{array}{l}\text { Nymphs. of gen. et spp, } \\
\text { ArgIOPIDAE }\end{array}$ & 49 & & & 9 & 8 & & 17 & 83 \\
\hline Neoscona doenitzi & 85 & & & 3 & & 1 & & 89 \\
\hline Singa pigmaea & 52 & & & & & & 2 & 54 \\
\hline Araneus cornutus & 2 & & & & & & & 2 \\
\hline Araneus sp. & 1 & & & & & & & 1 \\
\hline $\begin{array}{l}\text { Larinia sp. } \\
\text { LINYPHIIDAE }\end{array}$ & 1 & & & & & & & 1 \\
\hline $\begin{array}{l}\text { Linyphia sp. } \\
\text { TETRAQNATHIDAE }\end{array}$ & & & & & & & 1 & 1 \\
\hline Tetragnatha caudicula & 91 & & & & & & & 9 \\
\hline Pachygnatha clercki & 63 & & & & & 2 & 1 & 66 \\
\hline Tetragnatha japonica & 36 & & & 7 & 4 & 4 & & 51 \\
\hline $\begin{array}{l}\text { Tetragnatha shikokiana } \\
\text { Tetragnatha praedonia }\end{array}$ & $\begin{array}{r}37 \\
3\end{array}$ & & 5 & 1 & & & 2 & $\begin{array}{r}45 \\
3\end{array}$ \\
\hline $\begin{array}{l}\text { Nymps of gen. et spp. } \\
\text { AGELENIDAE }\end{array}$ & 21 & & & & & & & 21 \\
\hline $\begin{array}{l}\text { Tegenaria sp. } \\
\text { LycosidAE }\end{array}$ & 1 & & & & & & & \\
\hline Pirata subpiraticus & 440 & & & & 8 & 61 & 20 & 529 \\
\hline $\begin{array}{l}\text { Lycosa pseudoannulata } \\
\text { Pardosa sp. }\end{array}$ & $\begin{array}{l}4 \\
1\end{array}$ & & & & & & 4 & $\begin{array}{l}8 \\
1\end{array}$ \\
\hline OXYOPIDAE & & & & & & & & \\
\hline Oxyopes badius & 1 & & & & & & & 1 \\
\hline THOMISIDaE & & & & & & & & \\
\hline Misumenops tricuspidatus & 25 & & & 1 & & 2 & 1 & 29 \\
\hline $\begin{array}{l}\text { Xysticus sp. } \\
\text { SALTICIDAE }\end{array}$ & 14 & & & & & 3 & & 17 \\
\hline $\begin{array}{l}\text { Marpissa magister } \\
\text { ClubIONIDAE }\end{array}$ & 8 & & & & & 14 & 1 & 23 \\
\hline Clubiona japonicola & 20 & & & & & & 1 & 21 \\
\hline Clubiona kurilensis & 2 & & & & & & & 2 \\
\hline Nymphs of gen. et spp. & 64 & & & & & & 3 & 67 \\
\hline GNaphosidae & & & & & & & & \\
\hline Drassodes sp. & 1 & & & & & & & 1 \\
\hline Fam. et gen. unknown & 3 & & & & & & & 3 \\
\hline Total & 1,115 & 1 & 6 & 44 & 18 & 96 & 67 & 1,347 \\
\hline
\end{tabular}

Note : Localities A-G denote Suweon, Pyongtek, Seochon, Gochang, Boseong, Jinju, and Kimhae, respectively. 
Table 2. Comparison of spiders collected by sucking and those by sweeping in the Suweon paddy field.

\begin{tabular}{|c|c|c|c|}
\hline Family & Species & Sucking & Sweeping \\
\hline \multirow{3}{*}{ LyCOSIDAE } & Pirata subpiraticus & 433 (31ððð 51 우우) & 7 (none) \\
\hline & Lycosa pseudoannulata & 0 & 4 (none) \\
\hline & Pardosa sp. & 0 & $1\left(1 \sigma^{\top}\right)$ \\
\hline \multirow{6}{*}{ TETRAGNATHIDAE } & Pachygnatha clercki & 60 (466, 13 우우) & 3 (16. 1q) \\
\hline & Tetragnatha caudicula & 13 (2우우) & 77 (10 フ オ, 13 웅) \\
\hline & Tetragnathe shikokiana & 5 (none) & 32 (4 $\sigma^{\pi} \sigma^{\pi}, 13$ 우우) \\
\hline & Tetragnatha japonica & 5 (2우우) & 31 (4우우 \\
\hline & Tetragnatha praedonia & 0 & $3\left(2 \sigma^{7}, 19\right)$ \\
\hline & Unknown nymphs & 14 & 7 \\
\hline \multirow{4}{*}{ ERIGONIDAE } & Gnathonarium dentatum & $19\left(6 \circlearrowleft^{x} \circ^{x}, 13\right.$ 우우 $)$ & $1\left(1 \sigma^{\top}\right)$ \\
\hline & Oedothorax insecticeps & $13\left(5 \sigma^{7} \sigma^{7}, 8-\mathbf{W}\right)$ & 0 \\
\hline & Erigone prominens & $3\left(2 \sigma^{\top}, 1\right.$ ๆ) & $2\left(2 \sigma^{\top} \sigma^{\top}\right)$ \\
\hline & Unknown nymphs & 47 & 2 \\
\hline \multirow{4}{*}{ THERIDIIDAE } & Achaearanea sp. & $32\left(4 \sigma^{\top} \sigma^{x}, 4\right.$ 우우) & 0 \\
\hline & Enoplognatha japonica & $16(2$ 우우 $)$ & 0 \\
\hline & Theridion subpallens & $2\left(1 \sigma^{\top}, 19\right)$ & 0 \\
\hline & Steatoda sp. & 2 (none) & 0 \\
\hline \multirow{3}{*}{ Clubionidae } & Clubiona japonicola & $5\left(3 \sigma^{x} \sigma^{\pi}, 2\right.$ 우우 & 15 (4ه $\sigma^{\top}, 11$ 우우 \\
\hline & Clubiona kurilensis & $2\left(1 \sigma^{\pi}, 1\right.$ 우 $)$ & 0 \\
\hline & Unknown nymphs & 31 & 33 \\
\hline \multirow{5}{*}{ ArgiopidaE } & Singa pygmaea & 17 (2ððð 2 우우) & $35\left(7 \sigma^{7} \sigma^{\pi}, 14\right.$ + $\left.q\right)$ \\
\hline & Neoscona doenitzi & $4\left(1 \sigma^{x}\right)$ & 81 (7のるフ, 7우우) \\
\hline & Larinia sp. & 1 (none) & 0 \\
\hline & Araneus cornutus & 0 & 2 (none) \\
\hline & Araneus sp. & 0 & 1 (none) \\
\hline \multirow{2}{*}{ THOMISHIDAE } & Xysticus sp. & 10 (none) & 4 (none) \\
\hline & Misumenops tricuspidatus & 2 (none) & $23\left(3 \sigma^{\pi} \sigma^{7}, 1\right.$ 우 $)$ \\
\hline SALticidae & Marpissa magister & 1 (1우) & 7 (1 $10^{7}, 3$ 우우) \\
\hline Agelenidae & Tegenaria sp. & 1 (none) & 0 \\
\hline GNAPHOSHIDAE & Drassodes sp. & 1 (1우) & 0 \\
\hline OXYOPIDAE & Oxyopes badius & 0 & 1 (none) \\
\hline Unknown & Unknown & 3 & 0 \\
\hline
\end{tabular}

Note: Figures in parentheses are adults. 
1969). In Argiopidae, the relative abundances of Singa pigmaea and Neoscona doenitzi were reversed between the two collecting methods. These two species are snarers, but S. pigmaea was commonly seen in lower part of rice hills and vice versa for $\mathrm{N}$. doenitzi. These lines of evidence indicate that unbiased information about fauna and relative abundance of spiders in paddy field is obtainable by sucking rather than by sweeping (see also Fig. 1).

Pirata subpiraticus and Pachygnatha clercki are known as the spiders well adapted to cold regions, and their rich abundances in Lycosidae and Tetragnathidae are reported from north-eastern regions in Honshu, the main land of Japan (Hamamura, 1969; Koyama, 1972 ; Kobayashi and Shibata, 1973). It is interesting that Tetragnatha shikokiana, whose distribution in Japan is known only in paddy fields in Shikoku (Yaginuma, 1960), is widely distributed in Korea (see Table 1).

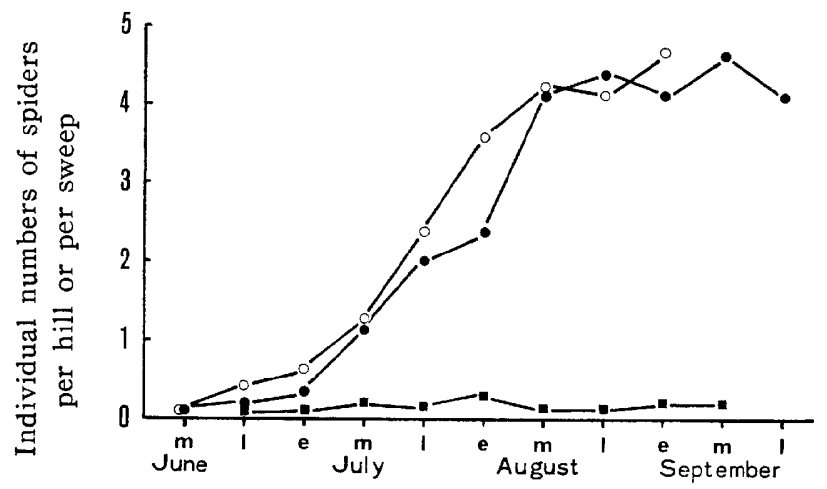

Fig. 1. Seasonal trends of total spider population as assessed by visual counting (- - ), sucking (-O-) and sweeping (- - ) conducted in the Suweon paddy field.

Fig. 1 shows the seasonal trends of total spider abundances assessed by visual counting, sucking and sweeping conducted in the Suweon paddy field. It is evident that the seasonal growth of total spider population was represented well by visual counting and sucking compared with sweeping which was unable to obtain unbiased samples of spider's fauna as already mentioned. Different pat terns of population growth of the respective spider species are involved in Fig. 1, but these will be reported elsewhere. In this paper, we describe- seasonal change in the diversity of spider's fauna and dominant species. For this purpose, Simpson's (1949) index of diversity was applied to the data obtained by sucking.

Simpson's index of diversity (6) is shown by $\delta=\sum n_{i}\left(n_{i}-1\right) / N(N-1)$, where $n_{i}$ and $\mathrm{N}$ are respectively the number of individuals of the ith species and that of individuals of whole species in the total specimens taken at a time. Simpson's index is thus the sum of probability that two individuals of the ith species belong to the same species if both individuals are drown at random from whole species of $\mathrm{N}$ individuals. It is apparent that $\delta$ takes values between 0 and 1 , and that values of $1-\boldsymbol{\delta}$ increase and decrease when species diversity increases and decreases, respectively. Also, Simpson's index is appropriate to detect the degree of dominance of each species by calculating the rate of contribution of each species to $\delta$ 
Table 3. Seasonal change in the diversity of spider's fauna and dominant spiders in the Suweon paddy field as shown by Simpson's (1949) index of diversity 6 .

\begin{tabular}{|c|c|c|c|c|c|c|}
\hline Period & $\begin{array}{l}\text { No. of } \\
\text { families }\end{array}$ & $\begin{array}{l}\text { Total no. } \\
\text { of } \\
\text { spiders }\end{array}$ & $1-\delta$ & Dominant families & Dominant species & $\begin{array}{l}\% \text { contribution of } \\
\text { dominant families } \\
\text { to the index } \delta\end{array}$ \\
\hline \multirow[t]{2}{*}{ mid June } & 3 & 16 & 0.492 & LYCOSIDAE & P. subpiraticus & 90.2 \\
\hline & & & & ERIGonidae & G. dentatum \& 0. insecticeps & 9.8 \\
\hline \multirow[t]{2}{*}{ late June } & 3 & 9.5 & 0.214 & Lycosidae & P. subpiraticus & 99.4 \\
\hline & & & & Lycosidae & P. subpiraticus & 81.6 \\
\hline \multirow[t]{4}{*}{ early July } & 7 & 102 & 0.688 & ERIGonidae & G. dentatum \& 0. insecticeps & 8.7 \\
\hline & & & & Tetragnathidae & P. clercki \& T. caudicula & 4.2 \\
\hline & & & & THERIDIIDAE & Achaearanea sp. \& E. japonica & 3.5 \\
\hline & & & & TheridiIdae & Achaearanea sp. & 44.5 \\
\hline \multirow[t]{3}{*}{ mid July } & 7 & 61 & 0.767 & Lycosidae & P. subpiraticus & 40.0 \\
\hline & & & & ERIGonidae & G. dentatum \& 0. insecticeps & 10.5 \\
\hline & & & & Lycosidae & P. subpiraticus & 88.9 \\
\hline \multirow[t]{2}{*}{ late July } & 8 & 131 & 0.723 & Erigonidae & G. dentatum \& 0. insecticeps & 6.1 \\
\hline & & & & THERIDIIDAE & Achaearanea sp. \& E. japonica & 2.5 \\
\hline \multirow[t]{2}{*}{ early August } & 6 & 127 & 0.497 & Lycosidae & P. subpiraticus & 95.2 \\
\hline & & & & Tetragnathidae & P. clercki \& T. caudicula & 2.3 \\
\hline \multirow[t]{2}{*}{ mid August } & 8 & 90 & 0.665 & LYcosidae & P. subpiraticus & 84.1 \\
\hline & & & & Tetragnathidae & P. clercki \& T. caudicula & 11.4 \\
\hline \multirow[t]{2}{*}{ late August } & 6 & 35 & 0.633 & LYGosidAE & P. subpiraticus & 73.9 \\
\hline & & & & Tetragnathidae & P. clercki & 25.2 \\
\hline \multirow[t]{2}{*}{ early September } & 8 & 85 & 0.719 & Lycosidae & P. subpiraticus & 73.9 \\
\hline & & & & Tetragnathidae & P. clercki & 20.9 \\
\hline
\end{tabular}


as $n_{i}\left(n_{i}-1\right) / \sum n_{i}\left(n_{i}-1\right)$. In applying Simpson's index to the data, the basic taxonomic unit was family instead of species because all the nymphal stages of Erigonidae and Clubionidae and some nymphs of Tetragnathidae were unknown of their belonging species. Also, the data were grouped by 10 -day period from mid June to early September. The results are shown in Table 3.

As shown by the seasonal change of the diversity index, the spider's fauna was relatively poor in early period of rice growth (June), but it became rich thereafter except in early August. Pirata subpiraticus (Lycosidae) and Gnathonarium dentatum and Oedothorax insecticeps (Erigonidae) were the main early settlers in the paddy field. However, the population growth of the erigonids was not remarkable compared with $P$. subpiraticus, and became minor species from early August onward. Whereas P. subpiraticus was the most dominant species throughout the whole period. In early July, tetragnathids (mainly Pachygnatha clercki) and theridiids (mainly Achaearanea sp.) became fairly noticeable in number, and the population of theridiids became almost equal in abundance to that of $P$. subpiraticus in mid July. However, the population of theridiids rapidly declined after the peak and was deprived of its dominance position by the tetragnathid, $P$. clercki, which remarkably increased from early August onward. Thus, the two hunting species, $P$. subpiraticus and $P$. clercki, seem to be most important predators of rice leafhoppers in the paddy field.

\section{Summary}

Seasonal change in fauna and abundance of spiders in a paddy field in Suweon, a district in mid Korea, was regularly investigated from June to September in 1975 by two collecting methods, viz. sucking with an aspirator and sweeping with a butterfly net. Occasional collections of spiders were also made at several paddy fields in the south and south-western coastal regions. As the result, spiders of 12 families consisting of at least 21 species were sampled (Table 1). Comparison of the two collecting methods showed that unbiased samples of the fauna and abundance were taken by sucking, but not by sweeping which was largely effective in collecting such spiders as tetragnathids and argiopids snaring at the crown part (Table 2 and Fig. 1). Simpson's (1949) index of diversity was applied to the data obtained by sucking in order to detect the seasonal characteristics of spider's fauna and dominant species (Table 3). Spider's fauna was relatively poor in early period of rice growth (June). Pirata subpiraticus (Lycosidae, hunter) and Gnathonarium dentatum and Oedothorax insecticeps (Erigonidae, snarers with a hunting habit) were the main early settlers. However, the seasonal population growth of erigonids was not remarkable compared with $\dot{P}$. subpiraticus which was the most dominant species throughout the rice growing seasons. From July onward, spider's fauna became rich with the invasion and population growth of later settlers. Among the later settlers, the poputation growth of Pachygnatha clercki (Tetragnathidae, hunter exceptional in this family) was most remarkable. Thus, $P$. subpiraticus and P. clercki seem to be most important predators or rice leafhoppers in the paddy field. 


\section{Acknowledgement}

The first author, Okuma, wishes to thank Prof. Y. Hirashima of Kyushu University for his kind guidance and encouragement to her study of spiders.

\section{References}

Hamamura, T. (1969) Seasonal fluctuation of spider population in paddy field. Acta Arach., 22 (2): 40-50. (In Japanese with English summary)

Hokyo, N., M. H. Lee and J. S. Park (1976) Some aspects of population dynamics of rice leaf hoppers in Korea. Korean Jour. Plant Pmt., 15 (3): 111-126.

Kobayashi, S. and H. Shibata (1973) Seasonal changes in population density of spiders in paddy fields, with special reference to the ecological control of the rice insect pests. Jap. Jour. Appl.Ent.Zool., 17 (4): 193-202. (In Japanese with English summary)

Koyama, J. (1972) Spiders in paddy fields in Akita Prefecture. Ann. Rept. Plant Prot. North Japan, 23: 127. (In Japanese)

Simpson, E. H. (1949) Measurement of diversity. Nature, 163: 688.

Yaginuma, T. (1960) Spiders of Japan in color. Hoiku-sha (Osaka \& Tokyo), 186 pp. (In Japanese) 